TOMAŽ ŠALAMUN

Translated from the Slovenian by Michael Thomas Taren and the author

\title{
GLAD TO MEET YOU, MRS. ŠAŠLJEVA
}

The brain, the cartridge falling from the gun onto the ice, is today kitschy black brick. I see, Morse code, the Museum of Modern Art, workers in boots holding back a puddle so it gathers around the leg like stars of

the Milky Way around the heavens. The constituion of logos is too soft, not humid enough, so I'll babble a bit today and tell you a true story. I definitely know my eyes are the harbor seal and the pollen,

that I'll build a tepee in Nova Scotia, exactly the same

my mom built us in the People's Park in Ptuj, so the guard had to call the City People Committee, the City People Committee the mayor Dr. Mazlu, Dr. Mazlu

my grandfather Dr. Franjo Šalamun, and so we became pale because of the horrid flashes of lightning, Dies Irae, Fatherland. We ate the pheasant in total silence and after the meal there were not the usual still hours

at the piano. My grandmother tried to save the situation and told us we'll have to give the chair for upholstery, that we now live under People's power and could please Cilka jump upstairs to see if baberle had finished her soup.

We were also informed Dr. Korošec hurt his leg with a shovel at the excavations, so Nini, Pupi, and Muci have now their father with the bleeding leg, and our subletter Miss Anica is, far out!, a professor 
of Latin and Greek. And truly today you can see her witchy epigraphics, edited jointly with her husband Dr. Jaroslav Šašelj, in Iowa University Library under the call number PS $3545 . \mathrm{H}_{117} \mathrm{~S}_{48}$. What a

coincidence, right, Mrs. Šašljeva, your book looks at mine across the shelf, totally something else compared to Ptuj in the year 1946 when we had to be squeezed because of that rented room. 